\title{
Beauty activity of extracts from Saurus chinensis by ultra-fine ground
}

\author{
Hye-Jin Park ${ }^{1}$, Ki-Tae Park ${ }^{2}$, Shin-Hyub Hong ${ }^{1}$, Na-Hyun Kim ${ }^{1}$, Mi-Jeong Park ${ }^{1}$, \\ Eun-Jin Hong ${ }^{1}$, Dong-Hyun $\mathrm{Ahn}^{3}$, Bong-Jeun An ${ }^{4}$, Young-Je Cho ${ }^{1 *}$ \\ ${ }^{1}$ School of Food science and Biotechnology/Food and Bio-Industry Research Institute, Kyungpook National University, \\ Daegu 41566, Korea \\ ${ }^{2}$ School of Culinary Art and Baking technology, Dongju College University, Busan 49318, Korea \\ ${ }^{3}$ Department of Food Science and Technology, Pukyong National University, Busan 48513, Korea \\ ${ }^{4}$ Department of Cosmeceutical Science, Daegu Hanny University, Gyeongsan 38578, Korea
}

\section{초미세 분쇄한 삼백초(Saurus chinensis) 추출물의 미용 활성}

\author{
박혜진 $^{1} \cdot$ 박기태 $^{2} \cdot$ 홍신협 $^{1} \cdot$ 김나현 $^{1} \cdot$ 박미정 $^{1} \cdot$ 홍은진 $^{1} \cdot$ 안동현 $^{3} \cdot$ 안봉전 $^{4} \cdot$ 조영제 $^{1 *}$ \\ ${ }^{1}$ 경북대학교 식품공학부/식품생물산업연구소, ${ }^{2}$ 동주대학교 외식조리제과계열, \\ ${ }^{3}$ 부경대학교 식품공학과, ${ }^{4}$ 대구한의대학교 화장품약리학과
}

\begin{abstract}
In this study, beauty food activities were determined for extracts of Saurus chinensis as functional beauty food. Tyrosinase inhibitory effect was increased as more 4 folds by ultra-fine grind technology than normal grind technology in ethanol extracts from Saurus chinensis. A ultra-fine ground technology was used to increase the extraction yield for bioactive compounds from medicinal plants. Tyrosinase inhibitory activity, which is related to skin-whitening, was confirmed to be $100 \%$ for ethanol extracts at $1,000 \mathrm{ppm}$ of phenolics. Anti-wrinkle activity was determined showing $30 \%$ of inhibition effect at above $1,000 \mathrm{ppm}$ phenolic concentration. The elastase inhibitory activity of water and ethanol extracts from ultra-fine ground Saurus chinensis showed higher inhibition activity than compared to extracts from normal ground Saurus chinensis. Astringent activity in ethanol extracts was determined showing over $70 \%$ at $250 \mathrm{ppm}$ of phenolics. Based on these results, Saurus chinensis extracts can be used as a functional beauty food and cosmetic with whitening, anti-wrinkle and pore contraction effects.
\end{abstract}

Key words : beauty food activity, extracts, Saurus chinensis, ultra-fine ground

\section{서 론}

광노화에서 자외선 중 특히 $\mathrm{UVB}$ 의 피부 노출은 superoxide anion radical, hydroxyl radical과 같은 활성산소 의 생성하게 되는데, 과량의 활성산소는 염증반응, 홍반, 화상, 면역억제, DNA손상 및 피부암을 일으키는 주요 요인 으로 작용한다 $(1,2)$. 태양에 노출된 피부표면은 노출되지

*Corresponding author. E-mail : yjcho@knu.ac.kr

Phone : 82-53-950-7755, Fax : 82-53-950-7762

Received 31 March 2016; Revised 8 September 2016; Accepted 26 September 2016.

Copyright (c) The Korean Society of Food Preservation. All rights reserved.
않은 부분보다 지질과산화물의 함유량이 높으며, 만성적으 로 태양에 노출된 부위에는 광노출에 의한 지질과산화 생성 이 증가되게 된다. 피부 최외각의 barrier층인 각질층의 지질 은 각질층 내 수분을 유지하고, 외부수분의 유입을 막는 기능을 수행하며 상피세포 증식조절, 세포 응집 및 표피세 포의 이탈에도 관여한다(3-5). 또한 자외선 노출은 피부의 각질층에 존재하는 지질을 산화시켜 피부장벽 구조의 손상 을 초래함으로써 피부의 수분유지 기능을 저하 시킨다(6). 현재까지 다양한 요인에 의한 피부노화의 억제 및 피부상태 의 개선을 위해 많은 연구가 진행되고 있으며 기능성 물질 들이 다양하게 개발되어 사용되고 있다 $(7,8)$.

최근에는 인체에 별다른 부작용이 없는 천연물질을 활용 한 피부개선에 많은 관심이 집중되고 있으며 우수한 피부개 
선 효과를 가진 안전성이 높은 천연물질에 대한 탐색연구가 활발히 진행되고 있다. 천연 피부개선 물질의 대부분은 우 리나라를 비롯한 동양권에서 오랜 기간 질병치료와 예방의 목적으로 사용되어온 한약재를 이용한 연구가 많으며, 식 용식물의 2 차 대사산물이 가지는 생체에 대한 생리활성 효과를 이용하는 천연재료로서 경험적으로 선택, 이용되어 인체에 대한 안전성은 검증된 것이라 할 수 있다(9-11).

삼백초의 주 분포지는 우리나라와 중국 및 일본 등 동북 아시아이며, 우리나라의 남부지방에서는 인공 재배되고 있 는 식물로서 예로부터 다양한 피부질환에 잎을 달여 마시거 나 즙을 내어 마시거나 병변 부위에 도포하는 방법으로 피부질환 및 해열, 해독, 소염, 소종 등의 내과적 질환에 전통적인 민간요법으로 사용 되어져 왔다 $(12,13)$. 삼백초에 함유된 주요 성분으로 hyperin, rutin, quercetin 및 quercetrin 등의 플라보노이드가 있으며(14), 최근 각종 연구에서 삼백 초내의 flavonoid 화합물이 주요 생리활성 물질임이 구명된 연구들이 보고되어 있다 $(15,16)$.

초미세 분쇄는 최근 기술로 식품 분야 및 화장품분야에 서 다양하게 응용할 수 있어 차세대 핵심기술로 각광 받고 있다(17). 초미세 분쇄에 의해 입자크기가 nano화됨에 따라 표면적의 증가와 capillary effect가 나타나게 된다. 표면적 증가는 연관된 촉매반응에 영향을 미쳐 생리활성 expression 의 변화 형태로 나타나게 된다 $(18,19)$.

따라서 본 연구에서는 초미세 분쇄한 삼백초로 부터 phenolic compounds을 분리하여 미용 활성 등을 규명하여 기능성 미용제품에 적용하기 위한 기초자료를 얻고, 천연 미용식품 및 천연 미용화장품의 소재 개발 가능성을 확인하 고자 하였다.

\section{재료 및 방법}

미쇄분쇄와 초미쇄분쇄 시료의 제조

본 실험에서 사용된 시료는 건조시킨 삼백초를 $10 \mathrm{~L}$ 용량 의 초미세 분쇄 장치(MKFS10-1, Koen 21 Co., Ansan, Korea) 를 이용하여 시간당 $20 \mathrm{~kg}$ 의 grinding 속도로 normal grinding(125 $\mu \mathrm{m}$ ISO mesh size, ASTM 40 mesh: 이상 사이 즈), fine grinding(125 $\mu \mathrm{m}$ ISO mesh size, ASTM 140 mesh: 초과 사이즈)과 ultrafine grinding(125 $1 \mathrm{~m}$ ISO mesh size, ASTM $140 \mathrm{mesh}$ : 미만 사이즈)으로 나누어 분쇄하여 사용 하였다.

\section{추출물의 제조}

시료 $1 \mathrm{~g}$ 에 증류수 $200 \mathrm{~mL}$ 를 넣고 액이 $100 \mathrm{~mL}$ 가 될 때까지 가열한 후 냉각하고 에탄올 추출물은 시료에 100 $\mathrm{mL}$ 의 $50 \%$ ethanol을 가하고 homogeniger로 $20,000 \mathrm{rpm}$ 에 서 1 분간 균질화 시킨 후 24 시간 동안 교반 추출하였으며,
추출액은 whatman No. 1 filter paper로 여과한 후 필요에 따라 rotary vacuum evaporator(Eyela NE, Tokyo, Japan)에서 농축하여 시료로 사용하였다.

\section{Phenol성 화합물의 정량}

Phenol성 화합물의 정량은 Folin과 Denis(20)의 방법으로 측정하였으며, 시료 $1 \mathrm{~mL}$ 에 $95 \%$ ethanol $1 \mathrm{~mL}$ 와 증류수 $5 \mathrm{~mL}$ 를 첨가하고 $1 \mathrm{~N}$ Folin-ciocalteu reagent $0.5 \mathrm{~mL}$ 를 넣어 잘 섞어주고, 5 분간 방치한 후, $5 \% \mathrm{Na}_{2} \mathrm{CO}_{3} 1 \mathrm{~mL}$ 를 가한 후, 흡광도 $725 \mathrm{~nm}$ 에서 1시간 이내에 측정하여 gallic acid를 이용한 표준곡선으로부터 양을 환산하였다.

\section{Tyrosinase 저해효과 측정}

Tyrosinase 저해활성 측정은 Yagi 등의 방법(21)에 따라 측정하였다. 반응구는 $0.175 \mathrm{M}$ sodium phosphate buffer $(\mathrm{pH}$ 6.8) $0.5 \mathrm{~mL}$ 에 $10 \mathrm{mM} \mathrm{L-DOPA}$ 를 녹인 기질액 $0.2 \mathrm{~mL}$ 및 시료용액 $0.1 \mathrm{~mL}$ 의 혼합액에 mushroom tyrosinase $(110$ $\mathrm{U} / \mathrm{mL}) 0.2 \mathrm{~mL}$ 을 첨가하여 $25^{\circ} \mathrm{C}$ 에서 2 분간 반응시켜 반응 액 중에 생성된 DOPA chrome을 $475 \mathrm{~nm}$ 에서 측정하였다. Tyrosinase 저해율(\%)은 1-(반응구의 흡광도/대조구의 흡광 도) $\times 100$ 으로 나타내었다.

\section{Elastase 저해효과 측정}

Elastase 저해활성 측정은 James 등의 방법(22)에 따라 측정하였다. 기질로서 N-succinyl-(L-Ala) 3 -p-nitroanilide를 사용하여 $37^{\circ} \mathrm{C}$ 에서 20 분간 기질로부터 생성되는 p-nitroanilide 의 생성량을 $445 \mathrm{~nm}$ 에서 측정하였다. 즉, 각 시험용액을 일정 농도가 되도록 조제하여 $0.5 \mathrm{~mL}$ 씩 시험관에 취하고, $50 \mathrm{mM}$ tris- $\mathrm{HCl}$ buffe $(\mathrm{pH}$ 8.6)에 녹인 porcine pancreas elastase $(2.5 \mathrm{U} / \mathrm{mL})$ 용액 $0.5 \mathrm{~mL}$ 을 가한 후 기질로 $50 \mathrm{mM}$ tris-HCl buffer(pH 8.6)에 녹인 N-succinyl-(L-Ala) 3 -p-nitroanilide $(0.5 \mathrm{mg} / \mathrm{mL})$ 을 첨가하여 20 분간 반응시켜 측정하였다. Elastase 저해율 $(\%)$ 은 1-(시료첨가군의 흡광도/대조구의 흡 광도) $\times 100$ 으로 나타내었다.

\section{수렴효과 검증}

Astringent 활성 측정은 Lee 등의 방법(10)에 따라 측정하 였다. 피부 단백질과 유사한 혈액 단백질(hemoglobin)을 사 용하여, 원심분리관 용기에 각각의 시료용액과 헤모글로빈 용액을 $1: 1$ 로 넣어서 진탕 혼합한 다음 $1,500 \mathrm{rpm}$ 에서 3 분 간 원심분리 후 $576 \mathrm{~nm}$ 에서 흡광도를 측정하였다. Astringent 활성은 1-(시료첨가군의 흡광도/대조구의 흡광 도) $\times 100$ 으로 나타내었다.

\section{통계처리}

실험 결과는 3번 이상 반복하여 측정한 후 평균값으로 나타내었으며, 실험결과의 통계분석은 SAS(Statistical 
Analysis System, SAS Institute Inc., Cary, NC, USA)의 Duncan's test를 이용하여 평균값간의 유의성 검정 $(\mathrm{p}<0.05)$ 을 하였다.

\section{결과 및 고찰}

초미세 분쇄가 삼백초 추출물의 tyrosinase 저해 활성 변화에 미치는 영향

초미세 분쇄기술은 해당 물질의 표면적을 극대화시켜 분해가 어려운 물질의 용해도를 증가시키며 유용물질의 추출 수율을 높이는 장점을 가진 기술로 기능성 물질의 효율적인 추출을 위한 가공방법이다. 최근 초미세 분쇄를 적용하여 기능성을 확인하는 다양한 연구가 진행되고 있으 며, $\mathrm{Cho}(23)$ 는 삼백초 잎으로 일반분쇄, 미세분쇄 및 초미세 분쇄 추출 등 추출방법을 달리하여 phenolic compounds의 용출량을 알아본 결과 물 추출물에서 일반분쇄 $6.2 \mathrm{mg} / \mathrm{g}$, 미세분쇄 $11.0 \mathrm{mg} / \mathrm{g}$, 초미세 분쇄 $12.9 \mathrm{mg} / \mathrm{g}$ 으로 보고하여, 일반 분쇄에 비해 초미세 분쇄 시 생리활성 물질의 추출 수율이 증가하는 것을 입증하였으며, 추출수율이 입자 크 기가 작아질수록 생리활성물질인 phenolic compounds의 추 출수율이 높아져 약 2.5 배 높은 추출수율을 나타내는 것을 확인할 수 있었다. 이상의 결과를 바탕으로 본 연구에서는 초미세 분쇄가 삼백초 추출물의 미백활성에 미치는 영향을 확인하였다.

사람의 피부색은 멜라닌(melanin)이나 카로틴(carotene) 과 같은 색소 성분 등에 의해서 좌우된다. 멜라닌이 피부색 을 결정하는 가장 중요한 요소로 국소적으로 과도하게 합성 되거나, 멜라닌 생성에 이상이 생기면 melanoma, freckle 및 hyperpigmentation을 유발하게 된다(24). 따라서 멜라닌 합성의 기질인 tyrosine을 분해하는 tyrosinase를 저해함으 로서 멜라닌의 합성을 억제하여 미백효과를 직접적으로 확인할 수 있으므로 많은 연구자들에 의해 tyrosinase 억제 효과를 검토함으로서 in vitro상에서의 미백효과를 검정하 고 있다(25-31). Tyrosinase 억제물질에 의한 산업적인 적용 은 최근 Vitamin $\mathrm{C}$, kojic acid, arbutin 및 hydroquinone 등의 천연 및 합성 미백제가 개발 연구되어 미백 화장품에 응용되고 있다. 그러나 Vitamin C, kojic acid와 같이 제한적 인 물질들만 상용화 되고 있어 상업적으로 이용 가능한 천연물을 활용한 미백활성을 가지는 물질에 대한 연구, 검 토가 필요하였다. 이에 따라 미세 분쇄와 초미세 분쇄된 삼백초의 미백활성 검증을 측정한 결과, Table 1 에서와 같 이 미세분쇄 하지 않은 삼백초 물 추출물의 경우 tyrosinase 억제 효과가 나타나지 않았지만 ethanol 추출물의 경우 미 세 분쇄한 삼백초에서 $10 \%$ 미만의 저해효과를 나타냈으며, 초미세 분쇄의 경우에는 $20 \%$ 이상의 미백활성 효과를 나타 내어 삼백초를 초미세분쇄 시 용출조건이 달라지면서 해당
물질의 표면적을 극대화시킴으로서 분해가 어려운 물질들 의 용해도를 높이고, 상대적으로 유용성 물질의 추출 수율 을 높여서 추출 또한 용이하게 됨으로서 tyrosinase 저해물 질이 추출됨을 알 수 있었다.

Table 1. Tyrosinase inhibition activity of Saururus chinensis extracts depanding on grinding methods

\begin{tabular}{ccc}
\hline \multirow{2}{*}{ Grinding methods } & \multicolumn{2}{c}{ Tyrosinase inhibition (\%) } \\
\cline { 2 - 3 } & Water extracts & Ethanol extracts \\
\hline Normal grinding & 0 & $5.6 \pm 0.6^{\text {1)a2) }}$ \\
Fine grinding & 0 & $7.5 \pm 1.3^{\mathrm{a}}$ \\
Ultra-fine grinding & 0 & $20.2 \pm 2.1^{\mathrm{b}}$ \\
\hline
\end{tabular}

${ }^{1)}$ The data were expressed as the mean $\pm \mathrm{SD}(\mathrm{n}=6)$.

${ }^{2}$ Means with different superscripts $(\mathrm{a} \sim \mathrm{b})$ in the column are significantly different at $\mathrm{p}<0.05$ by Duncan's test.

Tyrosinase는 $\mathrm{Cu}^{2+}$ 와 결합한 효소로 동 - 식물, 미생물 및 사람 등에 널리 분포되어 있는 polyphenol oxidase로 멜라닌 합성 과정에서 속도를 제한하는 등 멜라닌 합성의 주요한 조절적 단계를 나타내는 효소이다(28). Melanin 합성의 주 효소인 tyrosinase는 tyrosine을 3,4-dihydroxyphenyl-alanine (DOPA)으로 전환시키는데 관여하는 tyrosine hydroxylase 활성과, DOPA를 DOPA quinone으로 산화시키는 DOPA oxidase 활성을 가지고 있어 산화를 촉진한다(29). 그러므로 미백 성분의 소재의 melanin 생합성 과정의 특정 단계나 여러 과정을 동시에 저해하거나 차단시킴으로 인해 최종적 으로 미백효과를 기대할 수 있으며, 본 연구에서는 melanin 생합성에 관여하는 주요 효소인 tyrosinase에 대한 저해활성 을 in vitro 상에서 측정하여 미백활성을 확인하였다. 초미세 분쇄한 삼백초 ethanol 추출물의 phenolic compounds 농도 를 100 1,000 ppm으로 조절하여 tyrosinase inhibition test한 결과 Fig. 1 에서와 같이 삼백초 추출물의 경우에는 $500 \mathrm{ppm}$ 에서 $16.0 \%$ 의 저해효과를 나타내었으며, $1,000 \mathrm{ppm}$ 에서는 $100 \%$ 가까운 tyrosinase 저해 효과를 나타내는 것을 알 수 있었다. $\mathrm{Jee}(30)$ 은 상백피 추출물을 $1,000 \mu \mathrm{g} / \mathrm{mL}$ 농도로 첨 가하여 tyrosinase 저해효과를 살펴본 결과 ethanol 추출물에 서 $93 \%$ 의 저해활성을 확인하였다고 보고한 것과 유사한 결과를 나타내었으나, Lee 등(31)이 가죽나무 잎 추출물을 $2,000 \mu \mathrm{g} / \mathrm{mL}$ 의 농도로 조절하여 저해효과를 측정한 결과 $16 \%$ 의 tyrosinase 저해 활성을 나타내었다고 보고한 결과와 비교하면 삼백초 추출물의 미백효과가 월등히 우수함을 확인할 수 있었다.

최근 생명공학의 발달로 인해 미백 소재의 개발을 위한 여러 가지 연구가 제시되고 있으며, melanin 생합성 과정에 직접적인 영향을 주는 tyrosinase 활성 저해 측정을 비롯하 여 melanin 합성 후 전이 과정에 관여하는 신호전달체계를 생물학적 기법으로 확인하는 다양한 연구를 실시하고 있다 
(32-34). 본 연구에서는 초미세 분쇄가 삼백초 ethanol 추출 물의 미백 활성을 증대시키는 것을 확인하였으며, 향후 미 백 화장품 소재로 활용을 위한 연구 개발의 기초 자료로 활용될 수 있을 것으로 기대된다.

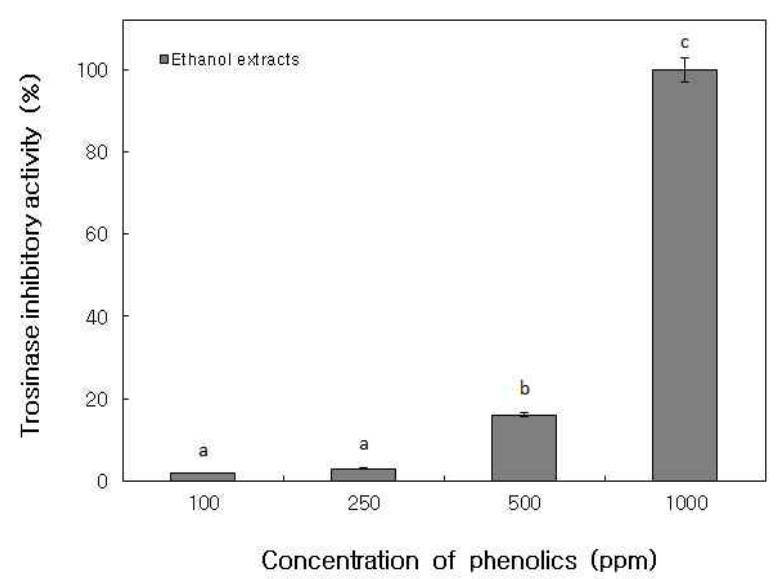

Fig. 1. Effects of phenolic concentration of Saururus chinensis on tyrosinase.

The data were expressed as the mean $\pm \mathrm{SD}(\mathrm{n}=6$ ). Means with different superscripts ( $\mathrm{a} \sim \mathrm{c})$ are significantly different at $\mathrm{p}<0.05$ by Duncan's test.

초미세 분쇄가 삼백초 추출물의 elastase 저해 활성에 미치는 영향

인체의 중성구 과립구내에 존재하는 elastase는 진피 내 피부탄력을 유지하는데 주요한 기질 단백질인 엘라스틴을 분해하는 효소이며, 다른 중요한 기질 단백질인 콜라겐을 분해할 수 있는 비특이적 가수분해 효소이다(35). 따라서 elastase 저해제는 피부 주름개선하는 작용을 나타내며, ursolic acid 등이 elastase 저해제로 이용되고 있다. 피부의 주름 증가와 탄력감소, 색소 침착 등이 노화의 대표적인 형태로, 그 중 가장 대표적인 노화의 현상은 바로 주름이다. Dewitt 등(36)은 이러한 주름을 생성하는 가장 대표적인 두 가지 요인은 자외선, 공해 등 외적인 환경요인과 나이가 들면서 발생하는 피부 조직의 내적요인이라고 하였다. Elastase는 피부조직내의 elastin을 분해함으로서 피부의 탄 력성이나 싱싱함을 잃게 하고 주름과 거칠어짐을 발생하여 피부의 노화를 촉진한다. 따라서 elastase 저해활성은 주름 개선의 효과와 상관있으며, elastase의 활성을 억제함으로 서 피부노화를 지연시킬 수 있음을 알 수 있다.

미세 분쇄와 초미세 분쇄된 삼백초의 주름개선 효과를 측정한 결과, Table 2에서와 같이 미세분쇄 하지 않은 삼백 초 물 추출물의 경우 elastase 억제 효과가 $11.4 \%$ 에서 초미 세 분쇄의 경우에는 $17.2 \%$ 로 증가하였으며, ethanol 추출물 의 경우 일반 분쇄한 삼백초의 $9.6 \%$ 에서 미세분쇄, 초미세 분쇄로 분쇄 입자의 크기가 작아질수록 $10.3 \%, 16.3 \%$ 로 높아지는 것을 확인할 수 있었다. 이는 tyrosinase 억제양상 에서와 같이 다양한 분쇄조건에 따라 용출조건이 달라지면
서 해당 물질의 용해도를 높이고, 상대적으로 유용성 물질 의 추출 수율이 높아져서 나타나는 현상으로 판단하였다.

Elastase는 체내의 엘라스틴을 분해하는 백혈구 과립 효 소 중의 하나로 이상조직에서는 그 효소의 활성이 극히 높아 조직 파괴에 직접적인 원인이 되어 피부주름 및 탄력 성 소실을 유발한다고 하였다(37). 초미세 분쇄한 삼백초의 phenolic compounds의 농도를 $100 ~ 1,000 \mathrm{ppm}$ 으로 조절하

Table 2. Elastase inhibition effect of Saururus chinensis extracts depanding on grinding methods

\begin{tabular}{ccc}
\hline \multirow{2}{*}{ Grinding methods } & \multicolumn{2}{c}{ Elastase inhibition $(\%)$} \\
\cline { 2 - 3 } & Water extracts & Ethanol extracts \\
\hline Normal grinding & $11.4 \pm 0.9^{1) 22}$ & $9.6 \pm 0.7^{\mathrm{a}}$ \\
Fine grinding & $12.8 \pm 0.2^{\mathrm{a}}$ & $10.3 \pm 0.6^{\mathrm{a}}$ \\
Ultra-fine grinding & $17.2 \pm 0.5^{\mathrm{b}}$ & $16.3 \pm 1.1^{\mathrm{b}}$ \\
\hline
\end{tabular}

${ }^{1)}$ The data were expressed as the mean $\pm \mathrm{SD}(\mathrm{n}=6)$.

${ }^{2)}$ Means with different superscripts $(\mathrm{a} \sim \mathrm{b})$ in the column are significantly different at $\mathrm{p}<0.05$ by Duncan's test.
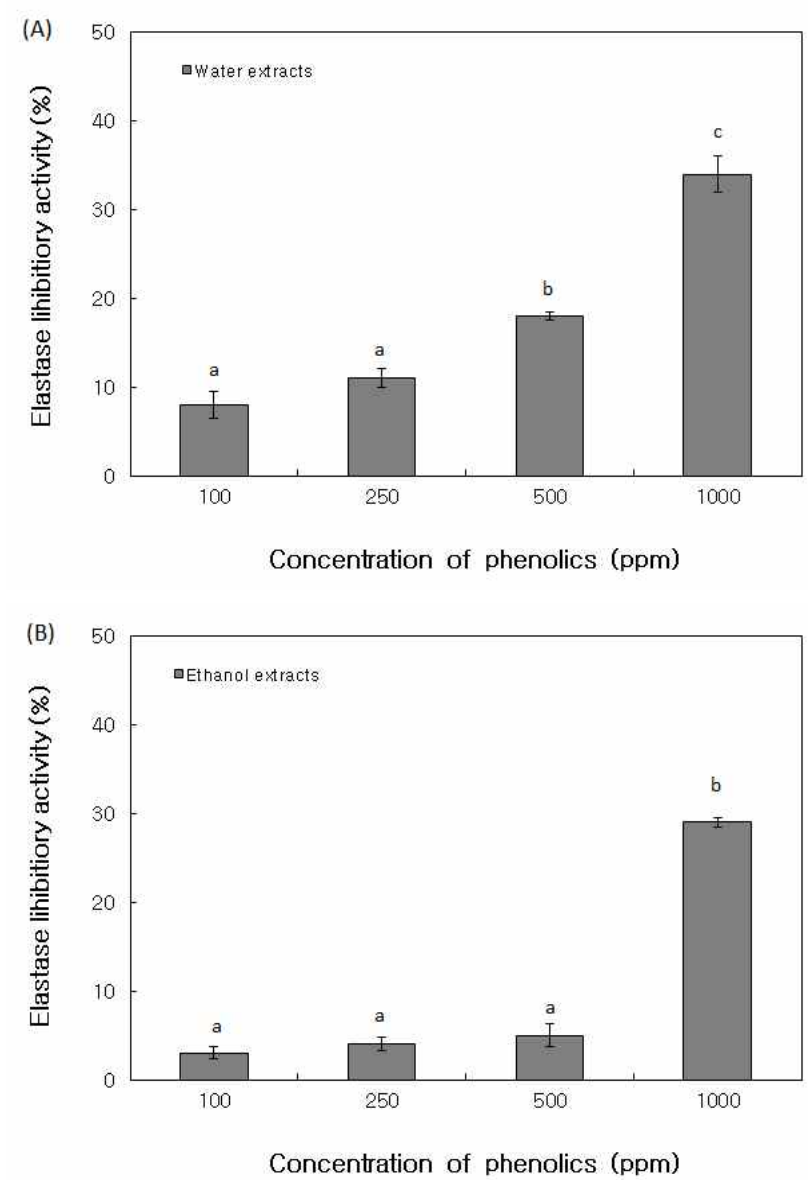

Fig. 2. Effects of phenolic concentration from Saururus chinensis on elastase.

A, water extracts; B, ethanol extracts.

The data were expressed as the mean \pm SD ( $n=6$ ). Means with different superscripts $(a \sim b)$ are significantly different at $\mathrm{p}<0.05$ by Duncan's test. 
여 elastase 저해활성 측정한 결과 Fig. 2에서와 같이 삼백초 추출물의 첨가농도가 $1,000 \mathrm{ppm}$ 의 농도에서 물 추출물과 ethanol 추출물에서 각각 $34.0 \%$ 와 $30.0 \%$ 의 저해효과를 나 타내었다.

초미세 분쇄가 삼백초 추출물의 수렴성에 미치는 영향

수렴작용이란 피부 단백질이 고분자 phenolic compound 와 가교결합을 형성하여 피부와 모공이 수축되는 현상을 말한다(38). 수렴제는 피부와 점막 혈관 등을 수축시키는 작용이 있고, 세포간극 및 림프간극을 막아 점액의 분비를 억제시키는 효과가 있다(39). 또한 수렴제는 단백질과 결합 하는 성질을 가지기 때문에 일반적으로 헤모글로빈의 단백 질이 추출물과 결합하는 정도에 따라서 수렴효과를 측정할 수 있다. Lee 등(39)은 이러한 수렴작용에는 피부와 점막의 표면에 난용성의 피막을 형성하여 구조를 보호하거나, 조 직을 조밀하게 하여 세포막의 투과성을 감소시키는 효과가 있다고 하였다.

초미세 분쇄 삼백초 물 추출물에서는 수렴효과가 관찰되 지 않았으며, ethanol 추출물의 phenolic 농도를 100 1,000 $\mathrm{ppm}$ 으로 조절하여 수렴성을 측정한 결과 Fig. 3에서와 같이 $250 \mathrm{ppm}$ 이상에서 $70 \%$ 이상의 좋은 효과를 보였으며, 1,000 $\mathrm{ppm}$ 의 농도에서는 $100 \%$ 에 가까운 astringent 효과를 나타 내었다. Lee 등(39)은 브로콜리 ethanol 추출물을 5,000 ppm 의 농도로 조절하여 astringent 효과를 측정한 결과 적색광 하에서 $51.6 \%$ 의 수렴효과를 나타내었다고 보고하였다. 또 한 Lee 등(10)은 함초 추출물 $10,000 \mathrm{ppm}$ 에서 $50.0 \%$ 의 astringent 효과를 나타냈다고 보고한 것과 비교하였을 때 낮은 농도에서도 $70 \%$ 이상의 효과를 나타낸 초미세 분쇄 삼백초 추출물의 수렴효과가 더 우수한 것이 확인되어 모공 축소 화장품에 적용이 가능할 것으로 판단되었다.

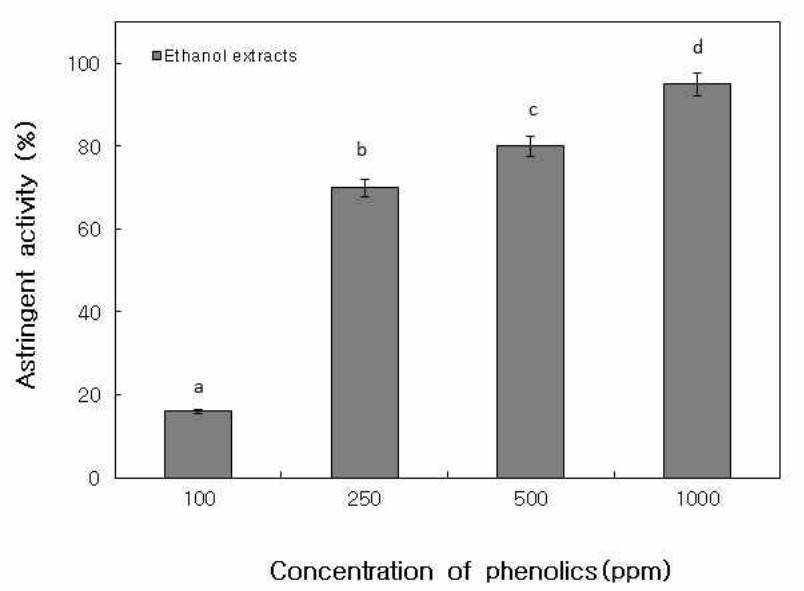

Fig. 3. Effects of phenolic concentration from Saururus chinensis on astringent.

The data were expressed as the mean $\pm \mathrm{SD}(\mathrm{n}=6)$. Means with different superscripts $(\mathrm{a} \sim \mathrm{b})$ are significantly different at $p<0.05$ by Duncan's test.

\section{요 약}

삼백초를 기능성 미용식품에 적용시키기 위하여 추출물 의 미용활성을 측정하였다. 삼백초 물 추출물의 경우 tyrosinase 저해활성이 나타나지 않았지만 ethanol 추출물의 경우 초미세 분쇄의 경우 $20 \%$ 이상의 미백활성 효과를 나타내어 삼백초를 초미세분쇄 시 tyrosinase 활성저해 물질 이 추출됨을 알 수 있었다. 삼백초 ethanol 추출물의 phenolic 농도를 100 1,000 ppm으로 조절하여 tyrosinase 활성 저해 를 측정한 결과 $1,000 \mathrm{ppm}$ phenolic 첨가농도에서 $100 \%$ 가까운 tyrosinase 저해 효과를 나타내었다. 주름개선 효과 는 삼백초의 phenolic 첨가농도가 $1,000 \mathrm{ppm}$ 이상의 농도에 서 $30 \%$ 내외의 저해효과가 있음을 알 수 있었고, 물 추출물 과 ethanol 추출물 모두 미세 분쇄보다 초미세 분쇄 추출물 이 더 우수한 elastase 저해활성을 나타내었다. 삼백초 ethanol 추출물의 수렴성의 경우 $250 \mathrm{ppm}$ 이상에서 $70 \%$ 이 상의 좋은 효과를 보였다. 따라서 초미세 분쇄한 삼백초 추출물은 일반 미쇄 추출물보다 미백, 주름개선 및 모공축 소 등의 미용 효능이 매우 우수한 것을 확인할 수 있었으며, 미백, 주름개선, 모공축소 등의 기능성 미용 소재로 적용이 가능할 것으로 판단되었다.

\section{감사의글}

이 논문은 지식경제부에서 2009년부터 2012년까지 시행 한 지역산업전략기획기술개발사업의 결과이며, 연구개발 비 지원에 감사드립니다.

\section{References}

1. Chiba K, Kawakami K, Sone T, Onoue M (2003) Characteristics of skin wrinkling and demal changes induced by repeated application of squalene monohydroperoxide to hairless mouse skin. Skin Pharmacol Appl Skin Physiol, 16, 242-251

2. Mukhtar H, Elmets CA (1996) Photocarcinogenesis mechanisms, models and human health implications. Photochem and Photobiol, 63, 356-357

3. Blanken R, Van Vilsteren MJ, Tupker RA, Conraads PJ (1989) Effect of mineral oil and linoleic acid containing emulsions on the skin vapour loss of sodium lauryl sulphate induced irritant skin reactions. Contact Dermatitis, 20, 93-97

4. Elias PM (1983) Epidermal lipids, barrier function, and desquamation. J Invest Dermatol, 80, 44-49 
5. Elias PM, Menon GK (1991) Structural and lipid biochemical correlates of the epidermal permeability barrier. Adv Lipid Res, 24, 1-26

6. Soter NA (1990) Acute effects of ultraviolet radiation on the skin. Seminars in Dermatology, 9, 11-15

7. Cho YJ (2011) Characteristics of cosmetic with whitening compounds from Phellodendron amurense. J Appl Biol Chem, 54, 108-113

8. Cho YJ, An BJ, Kim JH (2011) Application of isolated tyrosinase inhibitory compounds from Persimmon leaves. Korean J Life Sci, 21, 976-984

9. Choi SI, Lee YM, Heo TR (2003) Screening of hyaluronidase inhibitory and free radical scavenging activity in vitro of traditional herbal medicine extracts. Korean J Biotechnol Bioeng, 18, 282-288

10. Lee JT, Jeong YS, An BJ (2002) Physiological activity of Salicornia herbacea and its application for cosmetic materials. Korean J Herbology, 17, 51-60

11. Kim MJ, Kim JY, Choi SW, Hong JT, Yoon KS (2004) Anti-wrinkle effect of safflower (Carthamus tinctotius L.) seed extract. J Soc Cosmet Scientisis Korea, 30, 449-456

12. Lee ST, Park JM, Lee HK, Kim MB, Cho JS, Heo JS (2000) Component comparison in different growth stages and organs of Saururus chinensis Baill. Korean J Medicinal Crop Sci, 8, 312-318

13. Kim SK, Kim YH, Kang DK, Chung SH, Lee SP, Lee SC (1998) Essential oil content and composition of aromatic constituents in leaf of Saururus chinensis, Angelica dahuriea and Cnidium officiane. Korea J Medicinal Crop Sci, 6, 299-304

14. Choe KH, Yoon CH, Kwon SJ (1994) A study on chemical composition of Saururaceae growing in Korean on flavonoid constituents of Saururus chinensis. J Korean Soc Anal Sci, 7, 11-15

15. Kim BH, Song WS (2000) The dyeability and antimicrobial activity of silk and cotton fabrics with Saururus chinensis extract. J Korean Soc Cloth Ind, 2, 215-219

16. Lee JM, Son ES, Oh SS, Han DS (2001) Contents of total flavonoid and biological activities of edible plants. Korean J Dietary Culture, 16, 504-514

17. Lopez-Rubino A, Gavara R, Lagaron JM (2006) Bioactive packaging: turning foods into healthier foods through biomaterials. Trends Food Sci Technol, 17, 567-575

18. Kim KH, Lee IH, Lee HS, Park JK (2003) R\&D trend and information analysis of nanoparticles. Prospectives of Industrial Chemistry, 6, 46-61

19. Kim RY, Kim CS, Kim HI (2009) Physicochemical properties of non-waxy rice flour affected by grinding methods and steeping times. J Korean Soc Food Sci Nutr, 38, 1076-1083

20. Folin O, Denis W (1912) On phosphotungsticphosphomolybdic compounds as color reagents. J Biol Chem, 12, 239-249

21. Vincent J, Hearing Jr (1987) Mammalian monophenol monooxygenase(Tyrosinase): Purification, properties and reaction catalyzed. Methods in Enzymology, 142, 154- 165

22. James AEK, Timothy DW, Gorden L (1996) Inhibition of human leukocyte and porcine pancreatic elastase by homologues of bovine pancreatic trypsin inhibitor. Biochem, 35, 9090-9096

23. Cho YJ (2014) Antioxidant, angiotensin converting enzyme and xanthin oxidase inhibitory activity of extracts from Saururus chinensis leaves by ultrafine grinding. Korean J Food Preserv, 21, 75-81

24. Yamamura T, Onishi J, Nishiyama T (2002) Antimelanogenic activity of hydrocoumarins in cultured normal human melanocytes by stimulating intracellular glutathione synthesis. Arch Dermatol Res, 294, 349-354

25. Kim HS (2016) Anti-melanogenic effect of Eruca sativa extract. Korean J Food Preserv, 23, 74-79

26. Lee JY, Im KR, Jung TK, Yoon KS (2013) The inhibitory effects of Nelumbo nucifera Gaertner extract on melanogenesis. Korean Soc Biotech Bioeng J, 28, 137-145

27. Pak WM, Kim KBWR, Kim MJ, Park JH, Bae NY, Park SH, Ahn DH (2015) Anti-melanogenesis and anti-wrinkle effects of Sargassum micracanthum extracts. Microbiol Biotechnol Lett, 44, 19-25

28. Hearing VJ Jr (1987) Mammalian monophenol monooxygenase (tyrosinase): purification, properties, and reactions catalyzed. Methods Enzymol, 142, 154-165

29. Kouji Y, Hiroyuki S, Ken-ichi Y, Yasushi T, Shigeki $S$ (1994) Molecular cloning and functional analysis of a cDNA coding for human DOPAchrome tautomerase/ tyrosinase-related protein-2. Biochem Biophys Acta, 1217, 317-321

30. Jee SO (2009) Antioxidant activities and whitening effect of the mulberry (Morus alba L.) root bark extracts. Korean J Plant Res, 22, 145-151

31. Lee YS, Choi JB, Joo EY, Kim NW (2007) Antioxidative activities and tyrosinase inhibition of water extracts from 
Ailanthus altissima. J Korean Soc Food Sci Nutr, 36, 1113-1119

32. Hearing VJ, Jimenez M (1987) Mammalian tyrosinasethe critical regulatory control point in melanocyte pigmentation. Int J Biochem, 19, 1141-1147

33. Kameyama K, Takemura T, Hamada Y, Sakai C, Kondoh S, Nishiyama S, Urabe K, Hering VJ (1993) Pigment production in murine melanoma cells is regulated by tyrosinase, tyrosinase-related protein 1 (TRP1), DOPAchrome Tautomerase (TRP2), and a melanogenic inhibitor. J Invest Dermatol, 100, 126-131

34. Funasaka Y, Chakraborty AK, Komoto M, Ohashi A, Ichihashi M (1999) The depigmenting effect of a -tocopheryl ferulate on human melanoma cells. $\mathrm{Br} \mathrm{J}$ Dermatol, 141, 20-29

35. Tsuji N, Moriwaki S, Suzuki Y, Takema Y, Imokawa G (2001) The role of elastases secreted by fibroblasts in wrinkle formation: implication through selective inhibition of elastase activity. Photochem Photobiol, 74, 283-290
36. DeWitt DL, Rollins TE, Day JS, Gauger JA, Smith WL (1981) Orientation of the active site, and antigenic determinants of prostaglandin endoperoxide of synthase in the Endoplasmic reticulum. J Biol Chem, 256, 10375-10382

37. Roth GJ, Siok CJ, Ozols J. (1980) Structural characteristics of prostaglandin synthetase from sheep vesicular gland. J Biol Chem, 255, 1301-1304

38. Tsuji N, Moriwaki S, Suzuki Y, Takema Y, Imokawa G (2001) The role of elastases secreted by fibroblast in wrinkle formation: implication through selective inhibition of elastase activity. Photochem Photobiol, 74, 283-290.

39. Lee SY, Jun HJ, Yoon JY, Kim TS, Park SI, Lee SP, Park JH, Lee JY (2012) Cosmeceutical activity of broccoli (Brassica oleracea var. italica Plenck) with different light sources. J Life Sci, 22, 347-353 